Article

\title{
"El entendimiento con el qual me conoscan": Intellectual Mysticism in the Visión Deleitable
}

\author{
Michelle M. Hamilton
}

Center for Medieval Studies, University of Minnesota, Minneapolis, MN 55455, USA; hamilton@umn.edu

Received: 6 October 2019; Accepted: 17 December 2019; Published: 20 December 2019

check for updates

\begin{abstract}
Visión deleytable is a fictional tale based in the Aristotelian philosophical and Neoplatonic mystical beliefs of the Judeo-Arabic tradition of medieval Iberia. This fifteenth-century work of imaginative fiction, a "best-seller" among Iberian readers, tells of the ascent of the active intellect to the celestial spheres and an experience of God. In this narrative, knowledge of the Latin trivium and quadrivium are combined with that of the Arabo-Andalusi philosophic traditions. Particularly noteworthy is the author, De la Torre's extensive use of Maimonides' work, the Guide of the Perplexed, as a source for the wisdom revealed in the Visión deleytable. While Maimonides' position on the mystic experience is debated by contemporary scholars, in the present study I explore how the concept of intellectual mysticism, applied to the Neoplatonic/Aristotelian model of the intellect's conjunction with the divine as found in Maimonides' work, also describes the goal toward which the protagonist (and reader) of the Visión deleytable strive. As such, the Visión deleytable reveals how this notion of human-divine union (most notably in the concept of the "prophet-angel") from the Judeo-Andalusi tradition, transmitted in Arabic and Hebrew, was translated into Spanish and adopted into the Catholic and converso frameworks of the Visión deleytable in fifteenth-century Iberia.
\end{abstract}

Keywords: spanish medieval literature; converso literature; Maimonides; early print works; alfonso de la torre; spanish intellectual history; manuscript studies; prophecy; andalusi philosophy; spanish allegory

Alfonso de la Torre's Visión deleitable (Visión), composed c. 1440, is a narrative account of the ascent of the intellect and its experience of the Divine. It was a fifteenth-century best-seller and is a valuable testimony to the complex web of notions about how humans interfaced with God (the crux of the mystical experience) and offers hints about the texts and traditions that came to shape fifteenth-century Iberian intellectual history. ${ }^{1}$ Like the better-known mystic poet San Juan de la Cruz, active a century later, De la Torre offers an account of the interior journey of the individual to God, i.e., a mystical experience of the divine; however, while Juan de la Cruz uses poetry and prose commentary as vehicles for his account, De la Torre adopts an established Iberian prose tale genre to give form to this intellectual journey that culminates in a mystical experience. ${ }^{2}$ While for Juan de la Cruz and other Spanish mystics, the soul's union with God is an ecstatic, ineffable experience of God's grace and love,

1 Manuscript copies of the Visión were found in the libraries in all of the Iberian courts and there were eleven early modern print editions (García López 1991b, pp. 13-35).

2 Aaron Hughes calls this type of narrative an "initiatory tale," a fictional genre, based in philosophic beliefs in which the protagonist is "initiated into the secrets of the universe" after undergoing "existential changes in the course of their textual journey" (Hughes 2004, p. 19). Henry Corbin referred to this type of tale as a "visionary recital" (Corbin 1960; Hughes 2004, p. 33). Both Corbin and Hughes credit Avicenna as creating this type of tale. Hughes traces its development through Ibn Tufayl's Hayy ibn Yaqdan and Abraham ibn Ezra's Hebrew translation of Avicenna's tale of the same name, arguing that this genre of tales then disappeared, having "a relatively short career in Islamic and Jewish philosophy" (Hughes 2004, pp. 29,33-41). These tales are in and of themselves bridges in thought systems, particularly Neoplatonic thought and monotheistic religions: "These tales, then, essentially occupy the interface between the mythic worlds of Neoplatonism and 
for philosophic mystics (among which, I argue, we must include Alfonso de la Torre), the experience is the culmination of a rational process or journey during which the individual prepares their intellect to comprehend God. This essay explores the ways in which De la Torre conceives of the journey, the knowledge necessary to advance on it, the faculty of the mind that undertakes it, and the experience at the end of that journey (divine conjunction or union). It also locates this fifteenth-century Castilian tale in a long Iberian tradition of intellectual or philosophical mysticism. ${ }^{3}$ Developed in contrast to Sufi notions of mysticism as the ecstatic union of the individual with God, intellectual or philosophic mysticism describes a process by which the soul seeks direct union through the conjunction of the intellect (Lobel 2007, pp. 21-22). I explore in detailed readings of select passages of the Vision how De la Torre, using the Iberian vernacular, gives shape to his fifteenth-century version of intellectual mysticism. He is one of the last Iberian exponents of philosophic or intellectual mysticism, which had its origins among both early Christian and Muslim scholars (Augustine and al-Fārābī), and was then adopted by Andalusi thinkers, Muslim and Jewish alike (including Ibn Barrajān, Ibn Tufayl, Bahya Ibn Paquda, and Maimonides). ${ }^{4}$

The Vision survives in several fifteenth-century manuscript copies, including one in Hebrew aljamiado, as well as some early print editions (García López 1991b, pp. 13-34; Hamilton 2015, pp. 1-8). ${ }^{5}$ The author, Alfonso de la Torre, was a converso intellectual who studied at the University of Salamanca, and who likely served in the court of Charles of Viana, or Charles IV of Aragon (Hamilton 2015, p. 4). ${ }^{6}$ The work, dedicated to Juan de Beamonte, chancellor of Charles of Viana, in the surviving Romance copies, is a dream vision in which the narrator recounts how his intellect (Entendimiento) awakes in the middle of the night and undertakes a mental journey through the "houses" of the Liberal Arts, each personified as a learned woman who instructs him on the basics of their art, and then through the upper celestial spheres, ultimately acquiring all the knowledge necessary for his intellect to be actualized, i.e., capable of experiencing God. The narrator, Entendimiento or Intellect, first with the assistance of his innate ability (ingenio personal) ascends through a mental landscape by learning content and methods that allow him to proceed up the metaphorical mountain of knowledge. Entendimiento (and with him the reader) ultimately arrives to the celestial realms of the higher intelligences where, guided by the intelligibles personified as Wisdom (Sabieza), Reason (Razón), Truth (Verdad), and

that of monotheism (be it Islam or Judaism). In other words, both the structure and the mythic details of these tales draw their impetus not only from the Neoplatonic system, but also from the basic religious framework provided by the religious affiliations of the author" (Hughes 2004, p. 41).

3 Ibrahim Madhkour used the term "philosophical mysticism" to describe al-Fārābī's thought. David Blumenthal applied the term to Jewish thinkers, adopting it from the Muslim context (Blumenthal 2014). On Maimonides' philosophical mysticism, see also Freudenthal (2009). Lobel notes that in the wake of Blumenthal, such scholars as Georges Vajda, Alexander Altmann, and Pines in his later writings use the term. However, other scholars, including notably Menachem Kellner, maintain that Maimonides was a rationalist. See (Lobel 2007, pp. 21-22).

4 The work of earlier Muslim philosophers, such as al-Fārāb̄̄, Avicenna and Abū Hāmid al-Ghazālī, were jumping off points for Andalusi thinkers such as Ibn Barrajān, Ibn Rushd, Ibn Tufayl and Ibn 'Árabì. They all developed individualized approaches to the Neoplatonic scheme of the cosmos, according to which the material world (including humans) is related via a series of emanations or levels to a divine and unified source. See (Davidson 1992; Casewit 2017, pp. 35-37; Morewedge 1992). Neoplatonists, like Aristotelian scholars, shared a belief in a "mindful consciousness (nous, often translated as thought, intelligence, or intellect) [that] is in an important sense ontologically prior to the physical realm typically taken for ultimate reality (Mind over Matter)" (Wildberg 2019). These thinkers, even al-Ghazālī in his early writings, used Aristotelian methods such as logic and observation of the natural world, as well as theoretical concepts such as the Active Intellect to explain how humans connected to the divine. Mehdi Aminrazavi also calls the complex interweaving of Neoplatonic (cum Sufi) and Aristotelian thought in the medieval Muslim tradition "philosophical mysticism" (Aminrazavi 2016). Kreisel further notes that Judah Ha-Levi, Maimonides and Ibn Crescas' model was precisely this Andalusi Arab and Neoplatonic thought: "Islamic mystical and much of its philosophical literature provided them with a model for thinking of prophecy in this manner. This literature in turn was heavily influenced by Neoplatonic literature" (Kreisel 2001, p. 626).

5 One of the most tantalizing surviving manuscript copies of the Visión is a Hebrew aljamiado copy (i.e., a copy of this Castilian work in Hebrew characters) made in the first decades of the fifteenth century. On this copy, housed in the Biblioteca Palatina in Parma, Italy, see (Hamilton 2015, pp. 1-57). The Visión also survived in print editions in Amsterdam and was read by the likes of Fernando de Rojas, Lope de Vega and Solomon ibn Verga (Girón Negrón 2000, pp. 217-20).

6 Some of De la Torre's poetry has also survived, and he may have composed a now lost translation of Aristotle's Nichomachean Ethics. (Salinas Espinosa 1997, pp. 21-27; Hamilton 2015, p. 5). Girón Negrón, Salinas Espinosa and Hamilton explore the Visión as a converso text. 
Nature (Naturaleza), they ponder the metaphysical truths of the cosmos and the nature of God. De la Torre offers a narrativized synthesis of the Liberal Arts and moral and natural sciences of the medieval tradition, similar to earlier such synthesis, such as Shem Tov Ibn Falaquera's Sefer ha-Mevaqqesh (Book of the Seeker) or Ramón Llull's Libre des meravelles (Book of Marvels). Both Ibn Falaquera and Llull similarly adopt philosophical and theological insights to a fictional narrative of personal development, and similarly expand upon the earlier initiatory tale type of the Islamic and Jewish traditions to include material from medieval scholastic thought. ${ }^{7}$

De la Torre, in fact, acknowledges this debt by including some of the most important thinkers of the Islamic and Jewish traditions, including Avicenna, al-Ghazālī, al-Fārābī and Maimonides among the wise men Entendimiento encounters in the celestial realms:

arriving closer, he saw there a great company of very honored and wise men, all with glowing faces that made them seem like stars. He [Entendimiento] recognized among them some of the ancient ones, such as Acalo and Cecina, ${ }^{8}$ ancient Indians, and Hermes Termigisto and Alisanius, known later as Jupiter. And he also saw there Plato and other of his contemporaries. And from the moderns, he saw al-Fārābī, al-Ghazālī, Avicenna, and Moses of Egypt, as well as others worthy of great veneration who were among the company. And Entendimiento, in that glory and enjoyment that cannot be expressed in words, listened as Reason spoke before the blessed company.

llegándose más açerca vido allí una grant conpañía de omnes muy honrrados e muy sabios, todos con las caras ynflamadas que paresçía lunbre de estrellas. Entre aquéllos conosçió algunos de los antiguos, asy como Acalo [e] Çeçina, vetustísymos yndiacos, e el Termigisto e Alisanias, después llamado Júpiter. E vido allí al Platón e otros contemporáneos suyos. E de los modernos vido allí al Alfarabio, Algazel, Aviçena e Muysén de Egipto, e otros de grant veneraçión que eran en su compañía. E estando el Entendimiento en aquesta Gloria e folgança que non se puede explicar por palabra, la Razón fabló delante la bien aventurada conpañía. (De la Torre 1991, part1, chp. 15, p. 150)

De la Torre includes the twelfth-century Iberian Jewish thinker, Maimonides (here referred to as "Moses of Egypt"), who had done much of the intellectual labor of reconciling the Aristotelian ideas of al-Fārābī (as well as others not mentioned here, but whose works are cited elsewhere by De la Torre, including Ibn Bājja and Ibn Rushd, known in the West as Avempace and Averroes, respectively), to the "Sufi devotionalism" of such thinkers as al-Ghazālī and Avicenna (also mentioned above), and the prophetic wisdom of rabbinic traditionalism. ${ }^{9}$ Maimonides' works were transmitted and read in Hebrew among Iberian Jews in the centuries following his death. ${ }^{10}$ In addition, there was interest in Maimonides among Castilian Christian intellectuals in the fifteenth century, and one of Maimonides'

7 In the Sefer Ha-Meveqesh Ibn Falaquera (1976) similarly tells a fictional tale of a seeker who learns the basic sciences from different practitioners of them that he meets while undertaking a voyage in search of wisdom (Harvey 2014). Ramón Llull's fictional seeker, Felix, similarly journeys in pursuit of knowledge, culminating in the lessons on moral philosophy learned from a group of monks, who in turn cite their source as the fictional Libre de plasent visió (Book of the Delightful Vision). (Franklin Brown 2018, p. 385). Clearly Entendimiento, along with the seeker and Felix, are "textual protagonists" that "undergo profound existential changes in the course of their textual journeys" which culminate with initiation "into the secrets of the universe" and a "vision of the divine world" as Hughes (p. 19) defines the "initiatory tale" in his study of the work of Avicenna, Ibn Tufayl and Moshe ibn Ezra. Llull's and De la Torre's narratives suggest that the Judeo-Andalusi "initiatory tale" survived in the Romance vernaculars of the Peninsula.

8 These figures are not identified in the existing editions. They are also cited as authorities in the chapter on arithmetic (De la Torre 1991, part 1, chp. 6, p. 130). Acalo appears in several manuscript witnesses as Atalo, possibly a reference to Attalus of Rhodes (García López 1991a, p. 263).

9 (Lobel 2017, pp. 163-64). De la Torre also includes Ibn Rushd within Nature's house, together with Aristotle, Albertus Magnus and others (De la Torre 1991, part 1, chp. 30, p. 211).

10 Maimonides left Iberia and resettled in Egypt, where he became the court physician of the Ayybids and completed his best-known works, the Guide for the Perplexed and the Mishneh Torah (Stroumsa 2009; Halbertal 2013). On Maimonides' legacy, see (Halbertal 2013). 
best known works, the Guide of the Perplexed, was translated by the converso intellectual, Pedro de Toledo, between 1419 and 1432 (Fernández López 2011, p. 41). ${ }^{11}$

De la Torre, as scholars such as Luis Girón Negrón, Esperanza Salinas Espinosa and J. P. Wickersham Crawford have explored, created a narrative in which the Spanish-speaking reader would be presented, Cliffnotes style, with Maimonides' proofs and arguments for God's existence (as discussed below). Fewer details are included concerning the nature of the actual experience of knowing God, which is the accepted, de facto goal of all humans according to De la Torre. This experience is described repeatedly in the work as ineffable, but also as a vision and as a sensation of supreme happiness or eternal bliss, bienaventuranza, achieved through the "delightful vision" or visión deleitable of the work's title.

In the Vision this state is depicted as the fulfilment of one's potential as a human. In the Spanish, bienaventuranza is a loaded term, comparable to what Jewish and Muslim thinkers such as Avicenna, Maimonides, Abraham Abulafia (a kabbalist), and Ibn 'Arabī associate with union with God (ittihad in Arabic and osher in Hebrew). ${ }^{12}$ This happiness in its most perfect form is the intellectual union of the human mind and God:

Perfect happiness cannot exist, according to what we see proven in the first part of the Ethics, except through the intellect and in God in his glory, which will be on the one hand unity of potential and on the other His own perfection.

la bien aventurança perfecta no puede estar, segúnt las conclusyones que provamos en el comienço de la étyca, syno en el entendimineto e en Dios glorioso, lo qual el uno será asy como potençia e el otro asy como propia perfecçión suya. (De la Torre 1991, part 2, chp. 22, p. 336)

This happiness is explicitly based on the Aristotelian scheme (as defined in the Ethics) and can only be realized via the active intellect. This happiness is not only the goal for which all humans should strive, but is also the goal of Entendimiento within this fictional narrative. For Girón Negrón, this section of the Vision summarizes the entire work: "It summarily underscores the preeminent conclusion of Entendimiento's search: the intellectual apprehension of God in a 'delightful vision' as the mystical summum bonum of the religious life" (p. 204).

De la Torre reveals that the site of delectaçión or mystical happiness is the intellect, and, like Maimonides ${ }^{13}$, restricts this experience to the intellectual elite: "someone who is not an intellectual cannot achieve the delight of the intellect or comprehend the Lord of the ages" ("el omne non yntelectual non puede alcançar la delectaçión que es en el entendimiento e en conprehender del señor de los syglos," De la Torre 1991, part 2, chp. 22, p. 334). Later in the chapter, Reason tells the narrator that the highest level of perfection, experience of God, is an extreme happiness that is impossible to explain:

11 Fernández López notes that Pedro de Toledo's Castilian translation of the Guide is the product of the larger intellectual milieu of the Mendoza family (Fernández López 2011, p. 41). The latter, including figures such as Gómez and Lorenzo Súarez de Figueroa, Iñigo de Mendoza, the Marqués de Santillana are important patrons and producers of early Spanish humanist scholarship. For Fernández López, Maimonides' Guide conformed with certain humanist tendencies because in it Maimonides allegorizes a rational exegesis that reconciles Greek and Jewish thought (p. 41). While Pedro de Toledo's translation of Maimonides' Guide (Maimonides 1989) is roughly contemporary with De la Torre's Visión, it seems the latter, if he did consult it, opted to either use his own translation of the passages he uses from the Guide, or that De la Torre was working from a different, as of yet unknown Castilian translation (Salinas Espinosa 1997, p. 37; Girón Negrón 2000, p. 45). While it is not clear that De la Torre used Pedro de Toledo's translation, it is noteworthy that both of these converso intellectuals produced Maimonidean works in Castilian for Christian patrons within the larger milieu of the emerging humanism of the Iberian courts.

12 See (Tirosh-Samuelson 1998, 2003, pp. 20-21; Lobel 2017); and (Hamilton 2015, pp. 16-18, 110-13) for further discussion of the concept of 'osher in the Jewish traditions. Al-Ghazāli penned a treatise about this happiness, The Alchemy of Happiness, in which he states, "happiness is necessarily linked with the knowledge of God. Seeing, then, that nothing is higher than God, how great must be the delight which springs from the true knowledge of Him!... In truth, man in this world is extremely weak and contemptible; it is only in the next that he will be of value, if by means of the "alchemy of happiness" he rises from the rank of beasts to that of angels." (Al-Ghazāli 1909, pp. 30-32). The Arabic term ittihad (union) used to describe this state is also that used by Maimonides in the Guide 3.51 (Afterman 2016, p. 119).

13 (Maimonides 1981). 
"In [the experience of] this infinite bliss will be inestimable happiness that cannot be expressed" " $\mathrm{E}$ en aquesta aventurança perdurable será ynestimable alegría la qual non se puede explicar," p. 344). Reason is explicit that this bienaventuranza means knowledge of God ("Human bliss ... consists of coming near to God in his glory" "la bien aventurança de los omnes ... consyste en llegarse a Dios glorioso," p. 345). The ineffability of the mystical union, which Reason claims in this passage is concomitant to the bienaventuranza or bliss that accompanies the delightful vision, has long been identified with the mystic experience (Gellman 2019).

The path to this eternal bliss and mystical union requires the careful development of the intellect. The reader of the Vision accompanies the infant intellect, personified at the beginning of the work as the toddler, Entendimiento, who is helped along by his innate ability (ingenio natural) until he/it is capable of learning on his own, once he moves from the earthly to the celestial, from study of the arts to the moral and natural sciences. As Girón Negrón (pp. 80-99) examines in detail, De la Torre uses classical and Christian thinkers such as Isidore, Alain de Lille, Boethius, Pythagoras, Donatus, and Virgil embellished at points with the thought of scholars of the Arabic tradition, such as Avicenna and al-Ghazāli in the chapters dedicated to Entendimiento's earthly education in the Liberal Arts. In the information revealed by the intelligibles in the celestial realms, however, De la Torre presents the reader with several important ideas from Maimonides' Guide of the Perplexed. As mentioned, the Guide was translated from Hebrew into Castilian between 1419 and 1432 by the converso intellectual Pedro de Toledo; De la Torre's work, and its extensive readership, is evidence of the impact that Maimonides' thought had in fifteenth-century Iberia. The work was popular among Castilian, Catalan, Provençal and Italian Jewish intellectuals. ${ }^{14}$ The author of the Visión could also have been familiar with the Guide via the medieval Latin tradition, which included an anonymous thirteenth-century translation based on al-Harizī's Hebrew translation, but corrected using both the original Arabic text as well as Samuel ibn Tibbon's translation. ${ }^{15}$ De la Torre's indebtedness to the Guide is evident in chapters 10-18 of the Visión, in which Nature, Reason, Truth and Wisdom debate whether the doubting Entendimiento should be allowed in the celestial realms, their arguments reflecting Maimonides' concerns as expressed in the Guide (De la Torre 1991, part 1, chp. 31, p. 34; Crawford 1913, p. 194; Girón Negrón 2000, pp. 99-100). Wisdom then refutes the idea that there is no God, no purpose for man's existence, and that the universe is controlled by chance, using Maimonides' 26 proofs of the existence of God, presented in the Guide as a summary of Aristotelian premises (Maimonides 1963, part 2, chp. 1-3, pp. 235-54; Girón Negrón 2000, pp. 105-29).

In the Guide and his other works, Maimonides provides a model for reconciling the reason of Aristotelian thought with the direct experience of God from both the Arabic and Sufi traditions and the prophetic tradition of the Bible (Blumenthal 2014; Freudenthal 2009). Lobel notes that in the Guide (part 3, chp. 51), Maimonides instructs the reader that in order to achieve the ultimate end they must begin "with the study of mathematics and the biological and natural sciences" (Lobel 2017, p. 169). ${ }^{16}$ Similarly, De la Torre has Reason inform Entendmiento, who himself has mastered the Liberal Arts and natural sciences, that "men of judgement must understand that one works all his/her life to master scientific truth and to know the Lord, and that is what they must delight in" ("los omes que han juizio deven entender que él trabaja toda su vida en alcançar la verdad de las çiençias e conosçer el señor de lo que se deve delectar," De la Torre 1991, part 2, chp. 22, p. 335).

In the fifteenth-century Spanish context in which de la Torre lived and worked, the sciences took the form of the scholastic Liberal Arts, the basic curriculum at the medieval university, as well as the

14 (Rigo 2019, pp. 92-105).

15 (Rigo 2019, pp. 81-82). Di Segni, based on the use of vernacular terms, argues that this translation was made in either Spain or Italy (De Segni 2013, pp. cxi-cxxxiii). Rigo, though, notes that the marginalia in which these terms are found are not necessarily contemporary with the translation and do not necessarily reflect place of origin (Rigo 2019, pp. 84-85).

16 See Wolfson (1973) for a discussion of the study of Liberal Arts in Jewish and Andalusi traditions. Once mastering the scientific knowledge of the universe, then the individual should practice mindful meditation based on and springing from the Torah (Lobel 2017, p. 169). 
more advanced subjects of moral and natural philosophy, part of the curriculum for advanced degrees. Having mastered the Liberal Arts, Entendimiento arrives at Astrology's door-the threshold between earthly and celestial spheres, where he must wait to see if the queen of the celestial realm, Verdad (Truth), will grant him permission to enter. The reader is allowed to hear her conversation with her sisters in which she depicts Entendimiento as the active intellect of Neoplatonic thought: namely as originating in the divine, but tarnished by contact with hyle in the material world:

My lady sisters, God and you know how much it would please my heart to let Intellect in, for, as you know, our lineage and family origin were long ago the same as his, and because of that he is our very close relative. However, because of his long stay on earth where he lives, abominable opinions have been accepted by him.

Hermanas mías e señoras, Dios es sabidor e vosotras quánto gozo sería a mi coraçón la entrada de Entendimiento, el qual bien sabéys que otro tiempo fue desçendido de nuestro linaje e abolorio, e de allí es a nosotras pariente muy çercano, mas por la continuaçión que en la tierra ha fecho e morada le fueron añadidas abominables opiniones. (De la Torre 1991, part 1, chp. 9, p. 138)

Once among the intelligibles in the celestial realms, and having mastered the methods of thought and speech imparted by the Liberal Arts, Entendimiento is presented with proofs about the existence of God, and then about what role humans have in the universe. While the entire work serves as a roadmap for intellectual enlightenment, it is in dialogue with Wisdom and Truth that Entendimiento is allowed access to secret knowledge of God. It is in these chapters that the subject of prophecy is linked to the intellectual enlightenment that is the goal of Entendimiento's journey:

Sometimes the light of the intelligence is so bright in the intellect that it sees all things to come, as one who sees things in a mirror, and this happens when the soul has a perfect intellect and good habits, and because of this the soul is perfect. But other times the soul is not very good at speculation and it is less clean.

algunas vezes es la lunbre de la ynteligençia tan clara en el entendimiento que vee todas las cosas venideras, como quien vee ymágines en espejo, e esto es quando el ánima es perfecta en entendimiento e costunbres buenas, e aquésta tal es perfecta. E otras vezes el ánima es más flaca en especulaçión e menos linpia. (De la Torre 1991, part 1, chp. 28, pp. 202-3)

The ability to prophesize or see the future is contingent on having an enlightened intellect, which in turn, must be perfected through just the types of study and speculation that Entendimiento has undertaken.

The passages concerning prophecy in the Visión, which, like other parts of the work are deeply indebted to the work of Maimonides, offer valuable insights into how De la Torre conceived of how an individual could come to experience God and what the nature of that experience was like ontologically. De la Torre's framing of prophecy as an intellectual experience echoes the thought of earlier Iberian Jewish philosophers such as Judah Ha-Levi, Maimonides and Hisday Crescas, each of whom represent different approaches to prophecy, but all of whom base their thought on Andalusi philosophical thought. For them prophecy is a form of direct experience of the divine achieved by acquiring knowledge and perfecting the intellect. "In the case of these philosophers [Crescas, Halevi, Maimonides], a description of the phenomenon of prophecy is to a large degree implicitly a description of human perfection" (Kreisel 2001, pp. 625-26). However, Kreisel notes that while these thinkers have a great deal to say about how the individual can attain such happiness, they have "relatively little to say about the experience itself" (p. 626).

In the Vision, as in the earlier Judeo-Andalusi tradition, while the nature of union with the divine, bienaventuranza, is not extensively described, its opposite, the material world, tainted and corrupted by hyle or matter. Humans are hampered in their attempt to achieve bienaventuanza by their material 
reality - their body and surrounding material world, but angels, who exist beyond the material, in an eternal and incorruptible state, enjoy absolute happiness: "they delight in the beauty, the wisdom and bounty [of God]. And because glorious God will never die, and the angels will not die, this happiness is eternal, sure and incorruptible" ("se deleytan en la su fermosura [la de Dios], en la su sapiençia e en la su bondad. E porque Dios glorioso nunca fallesçe e los ángeles nunca fallesçen es esta bien aventurança eterna, segura e yncorruptible" De la Torre 1991, part 2, chp. 22, p. 337)

There is nothing mediating this happiness/bienaventuranza in the case of the angels. But humans exist in the material world, which tarnishes their understanding and keeps them from perfection. Entendimiento is capable of transcending the material world because he has acquired knowledge of the Liberal Arts and, when interrogated by Truth and her sisters at the gate to the celestial realms, he has an open mind (De la Torre 1991, part 1, chp. 13, p. 146). De la Torre, by way of his character Truth, gives a description of the direct experience of God's "glory and fullness," that relies on metaphors and comparisons, saying that this experience (the delight or deleite from which the work's title is derived) is infinitely superior to the earthly happiness experienced by humans and animals:

As for God, His bounty and glory are limitless as is His influence, and the blessed angels do not have any obstacle or impediment that prevents them from receiving it. And in that conjunction the delight is so great that it would be shameful to compare it to any other delight, for this delight is infinitely greater than any other imagined by humans, just as the delight of one man when he is made king is not comparable to that of the chicken when it eats some grain that its mother brings it: the difference between these delights [those experienced by the king versus that of the chick] does not compare to the difference between the delight of angels and humans [i.e., experienced by angels in contact with God, versus that of humans in contact with God].

E por quanto de parte de Dios glorioso se ynfluye la bondad e Gloria syn medida ninguna, e los ángeles bien aventurados non tienen obstáculo nin ynpendimiento nin que los estorve de la resçebir, e es en aquella conjunción la delectación tan grande que sería grant vergüença compararla a delectaçión ninguna, por quanto en ynfinito es mayor aquesta delectaçión que qualquiera delectaçión ymaginada por los omnes, que la delectaçión de un omne quando lo fazen rey conparada a la delectaçión de un pollo cuando come los granos que le busca su madre, es syn conparaçión, la diferençia de aquéllas es mayor que la de aquéstas." (De la Torre 1991, part 1, chp. 22, p. 337)

The author describes the angels' happiness as the unmediated experience of God, an experience the author uses the term "conjunction" to characterize. The noetic union or conjunction of the intellect with God, ittisal and ittihad in Arabic and devequt in Hebrew, had been adapted from Neoplatonism to the thought of important Iberian Muslim and Jewish mystics and philosophers, including Avicenna, al-Fārābì , Ibn Bājja, Ibn Tufayl, Ibn 'Arab̄̄, Judah Halevi, Ibn Falaquera, Moses of León, Isaac of Akko, and others (Davidson 1992, pp. 103-15, 134-43; Afterman 2016, pp. 60-101; Goodman 1996, p. 298; Wolfson 1994, p. 171; Fishbane 2009, pp. 243-44).

Maimonides, who had synthesized earlier Muslim and Jewish thought, and upon whom De la Torre relied for much of Truth and Wisdom's lessons, describes the relationship between God and man using this terminology. In part 3, chapter 51, Maimonides describes the union of the active intellect with the divine as "eschatological union" (ittihad) (Afterman 2016, p. 117). In the Guide Maimonides states clearly that this union with God is "apprehension of Him and love of Him," underscoring the central role of the active intellect: "That intellect which overflowed from Him, may He be exalted, toward us is the bond between us and Him" (Maimonides 1963, part 3, chp. 51, p. 624, p. 621). This union is realized only by the few: prophets and those who have perfected their intellects and separated themselves from "obstructions" of the material world. For scholars such as Afterman and Lobel it is here that Maimonides reconciles the mystical thought of earlier thinkers such as Avicenna, Ibn Bājja 
and the Sufi tradition with Aristotelian notions of the active intellect (Afterman 2016, pp. 117-19; Lobel 2017, p. 169).

While in the passage of the Visión cited above De la Torre has Reason explain to Entendimiento the relationship of angels and God, in her subsequent arguments she informs Entendimiento that the very truths she has revealed (recorded in the book we as readers are in the act of reading) allow the rational soul to partake of the conjunction/bienaventuranza that angels also experience in the celestial realms:

In addition to the angelic creatures, the others who enjoy this delight are the humans' rational souls, which can be classified into three types or levels. And may God in his glory be praised, for I have dared to describe for you the hidden secrets, knowledge of which is worth more than any price.

Los segundos que partiçipan este bien después de las criaturas angélicas son las ánimas raçionales de los omnes, las quales son en tres maneras o grados. E Dios glorioso sea alabado porque yo me atreví de descobrirte los secretos amagados los quales exçeden todo presçio conosçido. (De la Torre 1991, part 2, chp. 22, p. 337)

The three levels or types of rational human souls as conceived by De la Torre include those of the prophets, which are of three types: those who have a natural ability to prophesize ("a marvelous complexion and natural disposition," "maravillosa conplisyón e conpussyçión natural," 337); those who have an imaginative faculty that allows them to prophesize, and those who are wise and can prophesize thanks to their understanding/intellect ("wise men of accomplished intellect" "omnes sabios e conplidos de entendimiento," p. 337). De la Torre then gives examples of such men, including Abraham, Moses, and Jacob. All had prophetic dreams enabled by their imaginative faculty ("they had a very good imagination [which] appeared in dreams" "ellos ayan seydo de muy Buena ymaginaçión paresçe por los sueños," p. 338). He describes Abraham and Moses as accomplished natural philosophers and astrologers. Of Abraham and Moses he (through the character Reason) says that they came to understand the First Principle and First Cause on their own: "they were endowed by nature with knowledge such that they intuited naturally the existence of the First Principle and First Cause of the one, true God" ("tanto era su saber que naturalmente vino en conosçimiento de un primero prinçipio, e de cabsa primera de un solo Dios verdadero," p. 338). Here Alfonso de la Torre adopts the vocabulary of the Neoplatonist/Aristotelian tradition, having Truth describe God as the first cause or first principle, echoing Maimonides, who, as mentioned above, states that the source of humans' intellects is God.

Reason goes on to explain in detail how both Moses and Abraham experienced God much as the angels did, i.e., directly, without mediation:

And by means of their active intellect, through which they were friends of God and very close to and very like the angels, Our glorious Lord spoke to them [Abraham and Moses], not with a mouth or teeth as people think, nor by taking the form of a body of air, as others think, but by representing the things that will come to pass clearly in their intellects, just as the man who has good eyes sees the forms that are represented in the mirror, for the eye is very similar to the mirror's clarity.

E mediante el entendimiento faziente, con el qual eran amigos de Dios e muy çercanos e muy senblantes a los ángeles, Nuestro Señor glorioso fabló con ellos, no con boca nin con dientes, asy como las gentes entienden, nin tomando cuerpo de ayre, así como cuydan otros, mas representando en su entendimiento claramente las cosas que avian de ser, asy como el omne que tiene buenos ojos vee las formas que están en el espejo representadas, porque el ojo es muy semejante a la claridad del espejo. (De la Torre 1991, part 2, chp. 22, p. 338)

According to De la Torre, the prophecy of Moses and Abraham took place via the active intellect ("entendimiento faziente"). The latter makes them "friends of God," i.e., knowing him intimately. Thus, De la Torre's conception of prophecy and how these well-known prophets interacted with God 
conforms to Aristotelian/Neoplatonic notions of the human psyche and of humans' position in the cosmological hierarchy of beings.

De la Torre goes on to list biblical prophets (Noah, Lot, Joshua, Samuel, Elijah, Isaiah, Jeremiah) who had prophetic visions because of their developed intellects and ability to use the imaginative faculty: "they were very advanced in prophecy because of the great clarity and developed nature of their intellects ... and there were others whose intellects were not as purified or developed, but their imaginative faculty was very Good" ("fueron muy altos en la profeçía por la claridad grande e alteza de los entendimientos. E otros ovo cuyo entendimiento no fue tan purgado nin tan alto, enpero la su virtud ymaginativa era muy Buena," De la Torre 1991, part 2, chp. 22, pp. 339-40). For De la Torre, prophets, those who have a developed intellect or imaginative faculty, and through them, direct experience of God, are superior to other humans. They have achieved the highest level of perfection

among humans, because they are closer to the first grade of perfection, they are the lords and the kings over the other humans because they are closest to the First Cause, just as one who nears the fire will get warm. And they [prophets, lords, kings] have, while alive the vision of God and the byproduct of it, namely such great happiness and joy that all things in the world but it seem base mud, such that once they have tasted of that delight's sweetness, they think it a small thing that their son, wife or riches die away.

entre los omnes naturales por ser más çercanos del primer grado de perfecçión, e son señores e reyes de los otros omnes naturales por ser más çercanos del primer prinçipio, asy como quien más se allega al fuego más se escallenta, E aquéstos en su vida han la visyón de Dios e su fruyçión en la qual es la alegría e el gozo tan grande que, eçepto aquélla, todas la cosas del mundo les paresçe un poco de lodo, en guisa que quando de aquella dulçura han gustado en menos tienen el fijo nin muger nin riqueza que se mueran. (De la Torre 1991, part 2, chp. 22, p. 340)

Those who have achieved intellectual perfection have achieved the highest level of personal development and are accordingly closest to the divine, referred to using the Neoplatonic image of the First Cause or Principle.

In his description of the second type of person who has direct experience of God, those who develop their intellect with study of the Liberal Arts and natural philosophy, and who through a multitude of scientific demonstrations have the truth "planted in their souls" ("plantadas en sus ánimas"), De la Torre (through the lesson of Reason) makes it clear that, unlike the prophets, they are hindered more by the material realm:

And the second type of human, after the prophetic saints, consists of those who achieve good and penetrating intellects, having begun with a base in the Liberal Arts and achieving [through them knowledge of] the secrets of nature, and then with the true science they are afforded knowledge of the true and glorious God and his angels, and they achieve knowledge of the nature of the agent and the thing acted upon. And these things are established in their souls by a multitude of scientific demonstrations. And in this life, although their delight is infinitely more and better than that of other people, it is still not completely perfect, because of the impediment of the body. And once that impediment is removed, their soul will be conjoined with the King of the ages, and the delight will be so great that it would be stupid to compare it to base and corporal pleasures.

E la segunda manera de los omnes, después de los santos profetas, es de aquéllos que alcançan buenos entendimientos asaz penetrantes e han avido prinçipio en las artes liberales e han alcancado los secretos de natura, e con aquesto han proveydo en la çiencia verdadera e conosçimiento de Dios verdadero e glorioso e de sus ángeles, e han avido conplimiento de saber las naturas de las cabsas e los causados. E aquestas cosas están plantadas en sus ánimas por multitude de çientíficas demostraçiones ... 
Enpero en esta vida, maguer la su delectaçión sea un ynfinito mayor e mejor que todos los otros omnes, mas aún no es del todo perfecta, por cabsa del ynpedimiento del cuerpo, el qual ynpedimiento quitado, será la tal ánima conjunta al Rey de los syglos, e será la delectaçión tan grande que será torpeza conparalla a la delectaçión bestial e corporal alguna (De la Torre 1991, part 2, chp. 22, p. 341)

The individual who develops his intellect with study approaches the perfection of the celestial beings and has knowledge of God, but is not perfect, because he/she never succeed in transcending their human form, the hyle of the Aristotelian system. The latter is alluded to in the way De la Torre couches divine knowledge as an understanding of God and creation as the cause and its effects in the world ("los causados").

According to De la Torre and, as we have seen, Maimonides, shedding one's attachment to the material world, including the corporal body, is the goal of wise men and prophets, and what allows them to have mystical union.

The glory of heaven cannot be understood in this life except by a prophet or wise man. For they enjoy part of that glory, for when the soul separates from their flesh, as we have mentioned, that which was hidden is revealed, the wheat leaves the chaff, as the light emerges from the dark and the spark from the charcoal. And their souls ascend to the realm of the intelligences, and receive that Glory and that light and that goodness that all things desire, according to the first conclusion of the Ethics, for it is the ultimate goodness and culmination of all other goodnesses and it is infinitely better than all the others.

La gloria del çielo non se puede entender syno por el profeta o por el sabio en aquesta vida. Ca ellos gustan parte de áquella, enpero quando viene que de aquestas gentes que avemos dicho se parte el ánima de la carne e es manifiesto aquello que estava oculto, e sale el grano de la paja, e la luz de la tyniebla, e la çentella del tizón, e suben aquellas almas al syglo de las ynteligençias, e resçiben aquella Gloria, e aquella lunbre, e aquel bien, el qual todas las cosas desean por la primera conclusyón de la ética, aquél es bien postrimero por el qual son todos los otros bienes e é les mejor en ynfinito que todos los otros. (De la Torre 1991, part 2, chp. 22, p. 343)

De la Torre here describes what the realization or actualization of the intellect is like, using a series of metaphors: the separation of the wheat from the chaff, the light from the darkness, the flash of light from the coal. This act of separation allows the soul to then ascend to the realm of the intelligences where it can know God-the very realm, in fact, where this dialogue between Reason and the protagonist Entendimiento is taking place. Like Maimonides, who used the Arabic ittihad (and his Hebrew translators and successors devekut) to describe this union of human and God (Maimonides 1963, part 3, chp. 51, p. 624; Afterman 2016, p. 119), De la Torre uses the Romance adjunta, as we see above when Truth tells Entendimiento that perfection of the intellect allows the latter's soul to conjoin with God ("their soul will be conjoined with the King of the ages", "será la tal ánima conjunta al Rey de los syglos.")

In the Hebrew aljamiado version of the Visión, there is a telling variant that shows that at least in the Vision copied by and circulating among Jews and conversos (the only people who could read it in the Hebrew aljamiado), the concept of the prophet was identified with the realm of angels. In part 1 , chapter 29, Intellect asks Wisdom about the origins of the world, and the role of humans in it:

Entendimiento asked: "Why was this world created, and if what men say is true, namely that the angels, the heavens and the earth and all that is created by man, and finally man himself is created by God?" To which Wisdom replied: "All things in the world, large and small, were created by God, and He is the efficient cause and the final cause. Because of this it is said angel-prophet, which means first and last." 
Pregunto el Entendimiento: "El mundo, ¿para qué fue fecho? Sy es verdad lo que los omnes dizen, videlicet, que los ángeles e los çielos e la tierra e todo quanto es fue criado por el omne, e el omne fue final mente criado por Dios". A esto repuso la Sabieza: "Todas las cosas que en el mundo son, asy las altas como las baxas, fueron criadas por Dios e El fue la cabsa efiçiente e la causa final, e por tanto se dize profeta ángel, que quiere dezir primero e postrimero."17 (De la Torre 1991, part 1, chp. 29, p. 208)

Here, De la Torre offers an Aristotelian/Neoplatonic hierarchy of beings and explanation of the universe, according to which God, the Prime Mover or Cause is the source of creation (heavens and earth). He again has Wisdom explain the concept of the active intellect and its divine origins. But in the Hebrew aljamiado version the anonymous Jewish or converso copyist has introduced the variant "angel-prophet," alluding to a belief that had been developed among Judeo-Andalusi thinkers in the Peninsula to explain the Aristotelian/Neoplatonic concept of conjunction of the active intellect with and the divine Intellect from which it originated with the biblical and rabbinic traditions of prophecy. ${ }^{18}$ This Aristotelian/Neoplatonic view was accepted and disseminated via several of the authors of the Arabo-Andalusi tradition, including Avicenna and Maimonides. ${ }^{19}$ Avicenna posits this as the nature of prophecy: "The Angel is the necessary mediator between God and the Prophet, as the Prophet is the mediator between the Angels and the Sages, as the latter are mediators between the Prophet and the mass of mankind" (Corbin 1960, p. 109). In part 2, chp. 6 of the Guide, citing Genesis Rabbah, Maimonides says of the prophets: "Before they accomplish their mission, they are called men; when they have accomplished it, they are endued with the angelic state" (Maimonides 1963, p. 265). As discussed above, Maimonides, an important source for De la Torre, had framed prophecy as the transcendence of the material and metaphysical realms and as the transmutation of the human into angel via the active intellect. This angel-prophet, central to at least one contemporary reading of the Visión and at the heart of several preceding Iberian thinkers notions about how humans interface with the divine, is an expression of the paradoxicality that defines mystical experience (Gellman 2019, sct. 2.3).

This hyphenated being, the "angel-prophet"—-both human and supernatural—embodies the mystic experience as one that transcends the material world, the hyle of the Aristotelian world view and the world of sin of the Judeo-Christian ethos, offering a vision of the celestial or non-material realm of the divine. The concept of "angel-prophet" was central in the way that many medieval Jewish thinkers reconciled the Aristotelian/Neoplatonic notion of the active intellect and the rabbinic tradition of biblical prophecy. ${ }^{20}$ In part 2, chapters 6 and 7 of the Guide, Maimonides describes the angels in Genesis (19:21), Exodus (23: 21-31) and Deuteronomy (23:18) as expressions of Aristotle's separate intelligences (Maimonides 1963, pp. 262-66). He describes the Active Intellect as an angel-stating that "all forces are angels" (part 2, chpt. 6, 263). Further, Maimonides (Maimonides 1963, part 2, chpt. 6, p. 264) identifies the angel referred to as the "Prince of the World" in Scripture as the active intellect, "for from the activity of this angel all the sublunar forms derive" (Kreisel 2001, p. 220). Since, according to the Aristotelian/Neoplatonic beliefs that shaped Arabo- and Judeo-Andalusi thought, the active intellect is a part of the incorporeal divine that is its source, then the active intellect is the mechanism by which humans can transcend the material world and experience the divine, thereby enabling a mystic experience. In the Guide, Maimonides cites the Midrash Qoheleth:

17 I cite García López's edition, but include in italics this significant variant from the Hebrew aljamiado copy of MS Parma 2666.

18 In Beyond Faith, I discuss how and why the aljamiado copyist/s here substitute the concept of the profeta ángel for alpha et omega, a Christian concept and allusion to Christ (pp. 44-56).

19 Girón Negrón (2000, p. 138) discusses how Wisdom's answer reflects Avicenna's notion of human-angel relations. Corbin notes that Ibn Tufayl adopts Avicenna's soteriology, which is based on this concept: "Human souls, or more precisely their twofold intellective power, are the 'terrestrial angels' that have issued from the Tenth Archangel; this twofold power gives them a structure similar to that of the angelic pair that rules each heaven, with the difference that, through the exercise of this twofold power, it depends upon them whether they become angels or demons in actu." (p. 26).

20 See (Hamilton 2015, pp. 45-55). 
Midrash Qoheleth has the following text: When man sleeps, his soul speaks to the angel, and the angel to the cherub. Thereby they have stated plainly to him who understands and cognizes intellectually that the imaginative faculty is likewise called an angel and that the intellect is called a cherub... We have already spoken of the fact that every form in which an angel is seen, exists in the vision of prophecy. You will find that there are prophets who see the angels as if they were human individuals. Others from among them see [an angel] as if he were a man causing terror and amazement ... Consider how clear it is in every respect that the notion of angel is that of a certain act, and that every vision of an angel occurs only in a vision of prophecy and according to the state of him who apprehends. (Maimonides 1963, part 2, chp. 6, pp. 264-65).

In this passage, Maimonides describes the mystical unitive experience, when the imagination-a part of the intellect-is transformed into an angel, which is a special state that all occurs within the context of a nocturnal dream just like the one recounted in the Visión.

Such experiences-in which the individual has an experience of God-are not restricted to the biblical prophets according to Maimonides, but are open to those people who perfect their intellect, just as Entendimiento does in the Visión. Entendimiento, in fact, follows the course Maimonides describes in his Mishneh Torah:

[The individual seeking knowledge of God], when studying esoterical philosophy and [when] attracted by those elevated issues and ... of an appropriate temperament to understand and comprehend them, and sanctifies himself by moving away from anybody who concerns himself with ephemeral matters, and encourages himself not to have any thoughts about useless matters and its contrivances, [and] ha[s] his thoughts permanently attuned to above, from under God's Throne, to understand the pure and holy forms, and looks upon the wisdom of God [in Creation] in its entirety, from the first form [i.e the Holy Chayot] till the centre of the Earth, and sees in them God's greatness ... then prophecy will immediately come to him. At the time when prophecy comes to him, his soul will be on the same level as that of the Ishim angels, and he will become a different man, and he will realise that he is not [any more] as he was, but will rise above the level of other wise men, as it is written",... and you shall prophesy with him, and shall be turned into another man. (part 7.chp. 1)

The above passage from Maimonides ${ }^{21}$ reads like a summary of the Visión, which, as we have seen, tells of Entendimiento's shunning of the material world, his intellectual journey acquiring knowledge of the Liberal Arts, and natural and moral philosophy, and esoteric, metaphysical knowledge, and whose guide in the celestial realms include Wisdom, Reason, Nature and Truth. De la Torre provides his fifteenth-century Castilian-speaking audience with a narrative which takes the reader along with the protagonist through the stages of intellectual perfection. As mentioned, once Entendimiento moves into the celestial realm of the intelligibles, he has a vision of the wise men of the Arabo-Andalusi and Latin scholastic traditions, including Plato, al-Fārābī, Avicenna, al-Ghazālī, Maimonides, Aristotle and Ibn Rushd. He then proceeds on his intellectual journey, leaving these wise men behind, moving on to learn about the "wisdom of God" (proofs for His existence, the nature of creation and the cosmos), just as Maimonides describes the prophet doing in the passage above.

As in the Hebrew aljamiado copy of the Vision, in this passage the transformative nature of prophecy is underscored-it not only changes the prophet's nature from human to divine, but also turns the prophet into a different person. The prophet's intellect is elevated to the level of the angels. In the Visión, the intelligibles-Wisdom, Reason, Nature and Truth-fulfill the function of the ishim angels we find described above in Maimonides' Mishneh Torah. The latter explains how, in the course

21 (Maimonides 1993). 
of their enlightenment, the individual will encounter the 'ishim or 'human' angels (ishim being Hebrew for 'humans'). In the second chapter of the Laws, Maimonides defines such ishim angels as the lowest level of angels, closest to humans, and the vehicle for communicating and experiencing God: "The tenth level consists of the Ishim, who are the angel who speak with the Prophets and appear to them in prophetic visions. They are therefore called Ishim -'men'-for the reason that their level is closest to that of the intellect of Man" (part 2, chp. 7).

This Neoplatonic cosmovision is revealed to Entendimiento in his own prophetic vision-the Visión deleitable from which the work takes its name. Wisdom informs Entendimiento that God imagined the world into being:

Glorious God saw that it was Good to create a world which he had imagined within Himself, and he wanted that world to be like Him as much as possible, and he transmitted as much blessing to it as it was capable of receiving. And the angels took the first and purest perfection. And He saw the things as they would be in the world, namely the angels, and after them the intellects, the bodies, and the heavens ... and He said, beyond the angels and the heavens, what more noble creatures can there be, with no error in them? ... I want there to be people that have reason and use it, and who have intellect by which they can know Me, and [I want] that they obey Me and serve Me. And I want there to be among them prophets, kings, priests, soldiers, farmers, and others so that there is what they need. And this is the most and closest you can come to being like Me that they can understand. They will [eventually] be far from their origin and they will be changed so that very few of them will perfect their intellect to be like Me.

Dios glorioso ... vido que era Bueno fazer un mundo el qual Él tenia ymaginado en sy mesmo, e quiso que aquel mundo paresçiese a Él lo más que ser pudiese, al qual comunicó la mayor bondad que pudo resçebir, e los ángeles tomaron la primera perfecçión e la más pura. E vido todas las cosas avian de ser en el mundo, videlicet, los ángeles e después los entendimientos, e los cuerpos de los çielos ... E dixo, ultra de los ángeles o çielos, que son criaturas más nobles que ser pueden porque no ay error en ellos ... e quiero que aya omnes que tengan razón e usen de aquélla, e que tengan entendimiento con el qual me conoscan, me obedescan e me syrvan. E quiero que aya en ellos profeçía, reyno, sacerdoçio, miliçia e agricultura, e otras cosas que sean bastantes ... E ésta es la mejor e la más senblante a mí que ser pueda a ellos comunicada, ca por ser muy alongados de su prinçipio serán muy mudables, e pocos avrán perfecçión de entendimiento para que me senblen" (De la Torre 1991, part 1 chp. 25, pp. 182-83).

Wisdom urges Entendimiento (and the reader) to use his/their reason in contemplation of God; doing so will allow him (and all humans), who are so far removed in space and time from their origins in God as the First Cause, to be like Him. Wisdom further clarifies that in perfecting their rational faculty-the intellect-which is the goal of the Vision and what makes humans like God, they achieve perfection, the reason for creation and God: they become angel-prophets that appear at the end of the work, when Entendimiento has achieved perfection himself.

Several Iberian scholars who followed in Maimonides' footsteps, such as Abraham Abulafia and Moses de Burgos, became leading scholars of Jewish mysticism, and the concept of the prophetic angel continued to have valence in the mystical imagery of subsequent Iberian kabbalists. ${ }^{22}$ In fact, later notions of Jewish mystical experiences-the divine "visionary gnosis," as Kreisel notes, is for many kabbalists "phenomonolgically on a par with prophetic experience" (Kreisel 2001, p. 288). De la Torre

22 See the collection of studies dedicated to Maimonides and Mysticism in the special issue of $D a^{\prime} a t$ (Schwartz and Elqayam 1994). See also, (Hames 2009; Idel 1988; Hamilton 2015, pp. 51-52 for a detailed discussion of Moses of Burgos' conception of the ishim angels). 
and the copyist who created the Parma 2666 copy of the Vision firmly locate the work's narrative within this long Judeo-Andalusi philosophical and mystical tradition. Entendimiento's journey and process of learning is acquisitive and purifying - he must acquire the right forms of wisdom, in the right order, from the right sources, in order to achieve mystic illumination and intellectual perfection. In this De la Torre uses the "initiatory tale" form of Avicenna, Ibn Tufayl, Abraham ibn Ezra, Ibn Falaquera, and Llull. The goal of the tale's journey is ultimate happiness which is one and the same with knowledge of God. In the Vision this required perfection of the intellect, which was the vehicle by which one could transcend the material world and know God.

Armed with an encyclopedic knowledge of the logic and scientific methods developed among Andalusi and later scholastic scholars, De la Torres' intellectual ascent differs from that of other late medieval/early modern Spanish mystics such as Juan de la Cruz, even as he shares the goal of union/experience of God. While for some Christians the mystic experience is best expressed in an opaque poetry and in metaphoric images that capture but a fraction of the experience of union with God, for De la Torre rational argument and its tools—rhetoric, logic, the sciences-are the base upon which the individual develops his intellect to the point at which one can then achieve knowledge of the Divine. This form of philosophical mysticism, while less common in later Spanish literature and thought, had, before the fifteenth century, a long and established history among the intellectuals of the Peninsula working in a variety of languages-Arabic, Hebrew, Latin and Romance. As explored in this paper, De la Torre's work, the Visión deleitable, draws upon these traditions and intellectual history to create a fictionalized philosophical initiatory tale that shows the reader how they can develop their intellect in order to achieve their own mystical experience. Despite its difference from later forms of Iberian mystical expression, this tale of intellectual mysticism stands as a lasting testament to the many generations of preceding Iberian scholars whose thought helped shape De la Torre's vision.

Funding: This research received no external funding.

Conflicts of Interest: The author declares no conflict of interest.

\section{References}

Afterman, Adam. 2016. 'And They Shall Be One Flesh:' On the Language of Mystical Union in Judaism. Leiden: Brill. Al-Ghazālī, Abū Hāmid Muhammad ibn Muhammad. 1909. The Alchemy of Happiness. Translated by Claud Field. London: J. Murray.

Aminrazavi, Mehdi. 2016. Mysticism in Arabic and Islamic Philosophy. In Stanford Encyclopedia of Philosophy. Available online: https://plato.stanford.edu/archives/sum2016/entries/arabic-islamic-mysticism/ (accessed on 21 September 2019).

Blumenthal, David. 2014. Maimonides' Philosophic Mysticism. In Living with God and Humanity. Edited by Hava Tirosh-Samuelson and Aaron W. Hughes. Leiden: Brill, pp. 85-109.

Casewit, Yousef. 2017. The Mystics of al-Andalus: Ibn Barrajan and Islamic Thought in the Twelfth Century. Cambridge: Cambridge University Press.

Corbin, Henry. 1960. Avicenna and the Visionary Recital. Translated by William Trask. New York: Pantheon University Press.

Crawford, Wickersham. 1913. The Visión Delectable of Alfonso de la Torre and Maimónides's Guide of the Perplexed. Available online: www.jstor.org/stable/457040 (accessed on 2 October 2019).

Davidson, Herbert. 1992. Alfarabi, Avicenna and Averroes on Intellect: Their Cosmologies, Theories of the Active Intellect, and Theories of the Human Intellect. New York: Oxford University Press.

De la Torre, Alfonso. 1991. Visión Deleytable. Edited by Jorge García López. 2 vols. Salamanca: Universidad de Salamanca.

De Segni, Diana. 2013. Moses Maimonides and the Latin Middle Ages: A Critical Edition of Dux Neutrorum. Ph.D. dissertation, Università del Salento, Lecce, Italy.

Fernández López, José Antonio. 2011. Mostrador e enseñador de los turbados. Notas sobre el primer romanceado de la Guía de perplejos. Anales del Seminario de Historia de la Filosofía 28: 39-70. 
Fishbane, Eitan P. 2009. As Light Before Dawn: The Inner World of a Medieval Kabbalist. Stanford: Stanford University Press.

Franklin Brown, Mary. 2018. Ramón Llull as Encyclopedist. In A Companion to Ramón Llull and Llullism. Edited by Amy M. Austin and Mark D. Johnston Leiden: Brill, pp. 364-98.

Freudenthal, Gideon. 2009. The Philosophical Mysticism of Maimonides and Maimon. In Maimonides and His Heritage. Edited by Idit Dobbs-Weinstein, Lenn E. Goodman and James Allen Grady. Albany: State University of New York Press, pp. 113-15.

García López, Jorge. 1991a. Apparatus Plenus. In Visión Deleytable. Edited by Jorge García López. Salamanca: Universidad de Salamanca, pp. 219-439.

García López, Jorge. 1991b. Introducción. In Visión Deleytable. Edited by Jorge García López. Salamanca: Universidad de Salamanca, pp. 11-96.

Gellman, Jerome. 2019. Mysticism. Available online: https://plato.stanford.edu/archives/sum2019/entries/ mysticism/ (accessed on 16 August 2019).

Girón Negrón, Luis. 2000. Alfonso de la Torre's Visión Deleytable. Leiden: Brill.

Goodman, Lenn. 1996. "Ibn Tufayl". In History of Islamic Philosophy. Edited by Seyyed Hossein Nasr and Oliver Leaman. London and New York: Routledge, pp. 313-29.

Halbertal, Moshe. 2013. Maimonides: Life and Thought. Princeton: Princeton University Press.

Hames, Harvey J. 2009. Like Angels on Jacob's Ladder: Abraham Abulafia, the Franciscans, and Joachimism. New York: State University of New York Press.

Hamilton, Michelle M. 2015. Beyond Faith: Belief, Morality and Memory in a Fifteenth-Century Judeo-Iberian Manuscript. Leiden: Brill.

Harvey, Steve. 2014. Shem Tov Ibn Falaquera. 2014. Available online: https://plato.stanford.edu/archives/fall2014/ entries/falaquera/ (accessed on 21 September 2019).

Hughes, Aaron W. 2004. The Texture of the Divine: Imaginations in Medieval Islamic and Jewish Thought. Bloomington: Indiana University Press.

Ibn Falaquera, Shem Tov. 1976. Sefer ha-Mevaqqesh. Falaquera's Book of the Seeker (Part I). Translated and Edited by M. Herschel Levine. New York: Yeshiva University Press.

Idel, Moshe. 1988. The Mystical Experience in Abraham Abulafia. Translated by Jonathan Chipman. Albany: State University of New York.

Kreisel, Howard Theodore. 2001. Prophecy: The History of an Idea in Medieval Jewish Philosophy. Dordrecht: Kluwer.

Lobel, Diana. 2007. A Sufi-Jewish Dialogue: Philosophy and Mysticism in Bahya Ibn Paquda's Duties of the Heart. Pennsylvania: University of Pennsylvania Press.

Lobel, Diana. 2017. Philosophies of Happiness: A Comparative Introduction to the Flourishing Life. New York: Columbia University Press.

Maimonides. 1963. Guide for the Perplexed. Translated by Shlomo Pines. Chicago: University of Chicago Press.

Maimonides. 1981. Sefer Moreh ha-Nevukhim. Guide of the Perplexed. Translated by Samuel Yehuda Ibn Tibbon. Edited by Yehuda Kaufmann. Jerusalem: Mosad Harav Kook.

Maimonides. 1989. Mostrador e Enseñador de los Enturbiados. Guide for the Perplexed: A 15th-Century Spanish. Translated by Pedro de Toledo. Edited by Moshe Lazar. Dasgupta: Labyrinthos.

Maimonides. 1993. Maimonides: The Laws and Basic Principles of the Torah. Translated by Immanuel M. O'Levy. Jerusalem: Mossad Ha'rav Kook.

Morewedge, Parviz. 1992. Neoplatonism and Islamic Thought. New York: SUNY Press.

Rigo, Catarino. 2019. Dux neutrorum and the Jewish Tradition of the Guide of the Perplexed. In Maimonides' Guide of the Perplexed in Translation: A History from the Thirteenth Century to the Twentieth. Edited by Josef Stern, James T. Robinson and Yonatan Shemesh. Chicago: University of Chicago Press, pp. 81-140.

Salinas Espinosa, Concepción. 1997. Poesía y Prosa Didáctica en el Siglo xv: La Obra del Bachillar Alfonso de la Torre. Zaragoza: Prensas universitarias de Zaragoza.

Schwartz, Dov, and Avraham Elqayam. 1994. Maimonides and Mysticism. Da'at. A Journal of Jewish Philosophy $\mathcal{E}$ Kabbalah 33-34.

Stroumsa, Sarah. 2009. Maimonides in His World: Portrait of a Mediterranean Thinker. Princeton: Princeton University Press. 
Tirosh-Samuelson, Hava. 1998. Human Felicity-Fifteenth-Century Sephardic Perspectives on Happiness. In In Iberia and Beyond: Hispanic Jews between Cultures, Proceedings of a Symposium to Mark the 500th Anniversary of the Expulsion of Spanish Jewry. Edited by Bernard Cooperman. Newark: University of Delaware Press, pp. 191-243.

Tirosh-Samuelson, Hava. 2003. Happiness in Premodern Judaism: Virtue, Knowledge and Well-Being. Cincinnati: Hebrew Union College Press.

Wildberg, Christian. 2019. Neoplatonism. Available online: https://plato.stanford.edu/archives/sum2019/entries/ neoplatonism/ (accessed on 16 August 2019).

Wolfson, Harry Austryn. 1973. The Classification of the Sciences in Medieval Jewish Philosophy. In Studies in the History of Philosophy and Religion. Edited by Isadore Twersky and George H. Williams. Cambridge: Harvard University Press, pp. 478-92.

Wolfson, Elliot R. 1994. Through a Speculum that Shines: Vision and Imagination in Medieval Jewish Mysticism. Princeton: Princeton University Press.

(C) 2019 by the author. Licensee MDPI, Basel, Switzerland. This article is an open access article distributed under the terms and conditions of the Creative Commons Attribution (CC BY) license (http://creativecommons.org/licenses/by/4.0/). 